Journal of Animal and Veterinary Advances 11 (9): 1356-1361, 2012

ISSN: $1680-5593$

(C) Medwell Journals, 2012

\title{
Monitoring Red Deer and Roe Deer Population Density in Yedigoller-Yesiloz Wildlife Reserves in Turkey
}

\author{
Vedat Beskardes \\ Game and Wildlife Program, Vocational School of Forestry, Faculty of Forestry, \\ Istanbul University, 34473 Sariyer, Istanbul, Turkey
}

\begin{abstract}
Wildlife inventories are very new in Turkey. Thus, there is no enough data about red deer and roe deer population. However, these studies have gained momentum in recent years. In this study, it is aimed to determine and to monitor status of red deer and roe deer population densities. In the study, it was used a kind of drive count which was combined with point count. The study was conducted between 2003 and 2010 in October, once a year. Red deer and roe deer densities were determined between 0.45 and 1.19 red deer $/ \mathrm{km}^{2} ; 1.48$ and 2.05 roe deer $/ \mathrm{km}^{2}$. Also, average of annual growth rates were estimated for red deer $(0.135)$ and roe deer $(-0.0059)$. The study showed that whilst the red deer population has been increasing, roe deer population has been decreasing in long term period.
\end{abstract}

Key words: Red deer, roe deer, population density, wildlife reserve, annual growth, Turkey

\section{INTRODUCTION}

In wildlife management, all decisions and best management can be succeeded require information on density, on trend in density or on both (Caughley and Sinclair, 1994; Siddique Awan et al., 2004; Gundogdu, 2011). Knowledge of population size and population structure is essential for the development of effective management strategies for deer populations (Marques et al., 2001). Research into deer density and distribution helps in the selection of suitable additional feeding places (Qureshi et al., 2004; Costa et al., 2006). It also might be used to protect artificial plantations and naturally regenerating stands against browsing damage and to assist in rational game management in areas where the abundance of the deer populations controlled by culling (Prokesova et al., 2006).

To estimate density of wildlife populations, many models are developed, based on direct counts or indirect counts, e.g., line transects, quadrats, drive counts, point counts, aerial counts, mark-recapture and pellet counts (Al-Hashem, 2009; Pudyatmoko et al., 2009). The presence of Cervidae species in Anatolia dates back early Pleistocene. Deer were domesticated by Hittites and first record of deer farm was found around 2000 years ago in Bogazkoy-Hattusas. Wildlife habitats and populations were always under pressure of human activities, especially illegal hunting and habitat destructions for many years in Anatolia. In Turkey, Cervidae family has three species, red deer (Cervus elaphus L., 1758), roe deer (Capreolus capreolus L., 1758) and Fallow deer
(Dama dama (L., 1758)). Having involved in the study area Cervus elaphus and Capreolus capreolus population density and numbers were investigated in the research. Cervidae density has increased throughout Europe and North America (Milner et al., 2006). According to Kumbasli et al. (2010) deer populations in Turkey have been decreasing during the last 100-200 years because of uncontrolled hunting. Since, wildlife inventories are new in Turkey, there is no enough data about deer population. However, these studies have gained momentum in recent years. First study about red deer density and ecology was made by Ogurlu in CatacikEskisehir between 1989 and 1991. In this study, the population density was found $4.01 / \mathrm{km}^{2}$ by pellet counts.

According to Baskaya, the habitat where red deer can live is around $50000 \mathrm{~km}^{2}$, roe deer is around $100000 \mathrm{~km}^{2}$ but the number of red deer is 7000 and roe deer is 15000 in Turkey. In addition, The number of red deer and roe deer are tried to increase in their natural habitat because of their lower density. For this reason, Wildlife Reserves and wildlife breeding stations were established in Turkey. Wildlife populations need adequate quantity and quality of available resources for their survival (Patthey, 2003). Deer distribution is influenced by climatic factors, habitat structure, vegetation structure and food supply (Prokesova et al., 2006; Adrados et al., 2008). In Yedigoller region, it was conducted short-term wildlife counting study between 2003 and 2005 (Beskardes, 2009). However, if it is required to evaluate and improve a wildlife population, it should be monitored long-term period or counting processes should be never given up. 
Thus, the counting study was continued in the study area after 2005, between 2006 and 2010. To determine the density of deer population was used a kind of drive count which was combined with point count in the study area.

\section{MATERIALS AND METHODS}

Study site: Yedigoller-Yesiloz Wildlife reserve is located between $31^{\circ} 25^{\prime} 00^{\prime \prime}-31^{\circ} 55^{\prime} 00^{\prime \prime} \mathrm{E}$ longitudes and $41^{\circ} 05^{\prime} 00^{\prime \prime}$ $40^{\circ} 50^{\prime} 00^{\prime \prime} \mathrm{N}$ latitudes (Fig. 1). The study area is a protected area and hunting except for game tourism is prohibited entirely. Total 4-6 red deer and 6-8 roe deer are given as hunting quota yearly for game tourism in the area. In addition, the study area and its surroundings are a typical part of the Western Black sea region's high mountainous nature. The less rainy Black sea region climate is dominant in the area. For 71 years, the annual mean temperature is $10.2^{\circ} \mathrm{C}$ with the lowest temperature at $34^{\circ} \mathrm{C}$ and the highest temperature at $39.4^{\circ} \mathrm{C}$. The annual mean precipitation is $536 \mathrm{~mm}$ and average number of the rainy days is 137.7 day year ${ }^{-1}$. The altitude of the study area changes from $240-1982 \mathrm{~m}$.

The vegetation in the study area can be represented variety of the layers, e.g., herb, shrub and tree layers. Also this feature provides the animals feeding in all seasons in the study area. The main plant species determined in the area including Beech (Fagus sylvatica ssp. orientalis), Fir (Abies nordmanniana ssp. bornmülleriana), oaks (Quercus cerris, $Q$. frainetto, $Q$. petraea and $Q$. pubescens), Scots pine (Pinus sylvestris),
Austrian pine (Pinus nigra), Hornbeams (Carpinus betulus and Carpinus orientalis). The other important tree and shrub species are Common alder (Alnus glutinosa), strawberry tree (Arbutus unedo), Ash (Fraxinus excelsior), Cornellian cherry (Cornus mas), Mediterranean medlars (Crataegus orientalis, Crataegus pentagyna), European aspen (Populus tremula), European holly (Ilex aquifolia), Hazel (Coryllus avellana), Linden (Tilia tomentosa), Walnut (Juglans regia), Apple (Malus sylvestris), Maple (Acer campestre), Oriental plane (Platanus orientalis), Cherry (Prunus avium), English laurel (Prunus laurocerasus), Ornamental pear (Pyrus eleagnifolia), Rhododendron (Rhododendron ponticum), Grey willow ((Salix cinerea), Smilax excelsa, Common yew (Taxus baccata) and Field elm (Ulmus minor).

Counting method: Since, the study area is 50950 ha large, determining the entire area for wildlife populations' density and size has always required considerable amounts of time and money. Thus, it was decided to use sampling method in the study. First, wildlife reserve's $1 / 25000$ scaled maps were used to create a grid consisting of 509 units; each 100 ha total 50900 ha. Among 509 sample areas, 62 sample units represented $12.14 \%$ of the total area determined by randomly and considering financial means. Later on, the sample areas were examined on the field and their borders, streams and roads were drawn on the map. The map was digitalized in a GIS Program.

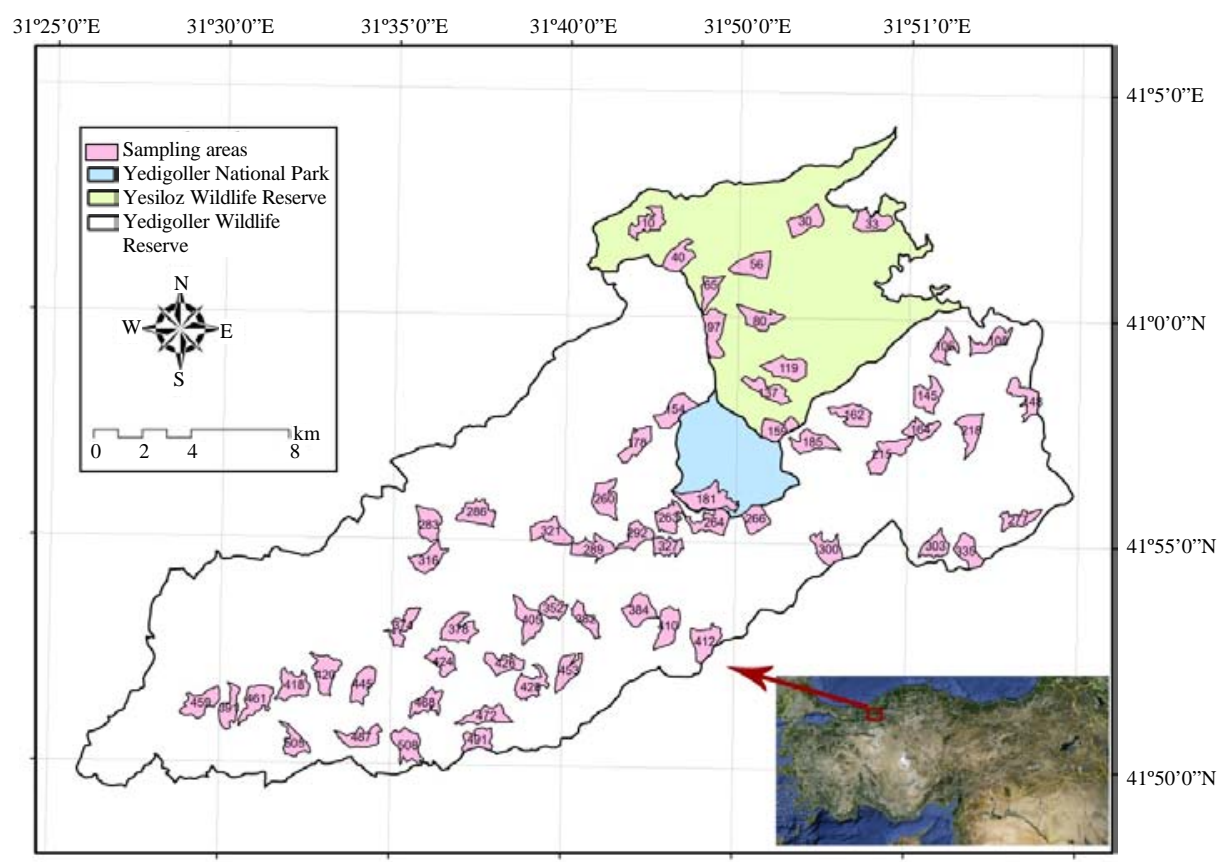

Fig. 1: Yedigoller-Yesiloz Wildlife Reserve sampling area 
In the study, it could be applied many counting techniques. However, a kind of drive count which was combined with point count and thought more appropriate for applying in the sampling units in the study. The counting was conducted between 2006 and 2010 years in October, once a year. Especially late October was chosen for counting and aimed to more clear observation because the broadleaf trees begin to shed their leaves late October in the study area. The counting data between 2003 and 2005 were provided from Beskardes (2009). Four sample areas were driven in a day and the counting procedures continued almost 16 days in a year.

For the drive counts, a counting team of roughly 25 people was employed. The team separated into two groups, driver and observer then the numbers of drivers and observers were determined based on characteristics of the sample area. Observers were left at the points on the paths and courses where the animals would pass. Drivers using rifles, blank guns and hooters, created noises to make the animals run towards the observers. All the animals within each sample area are assumed to have been counted. Observers recorded the numbers, gender and age groups of animals on their observation cards. Furthermore, during the counting process, drivers observed that some animals had run back, breaking through the drivers' line. These were also added to the bottom line after the counting. In neighboring sample areas, reverse directions were selected for driving the animals.

The data collected from the study area were analyzed by descriptive statistics ANOVA, Test of Homogenity of Variance, Kruskall-Wallis $\mathrm{H}$ test of K-Independent test. To estimate the animals' density the following equation were used. Since, the number of units is $n \geq 30$, the estimation of the population's total value is:

$$
\sum_{\mathrm{i}=1}^{\mathrm{N}} \hat{\mathrm{X}}_{\mathrm{i}}=\mathrm{N} \overline{\mathrm{x}} \pm \mathrm{Z}_{\alpha / 2} \mathrm{~N} \hat{\sigma}_{\overline{\mathrm{z}}} \sum_{\mathrm{i}=1}^{\mathrm{N}} \hat{\mathrm{X}}_{\mathrm{i}} \longleftrightarrow \sum_{\mathrm{i}=1}^{\mathrm{N}} \hat{\mathrm{X}}_{\mathrm{i}} \text { (lower bound) }
$$

Where:

$\mathrm{N}=$ Sampling size

$\mathrm{n}=$ Number of sample units $\hat{\sigma}_{\overline{\bar{x}}}=$ The standard deviation sample averages series

$\overline{\mathrm{x}}=$ The population average

To estimate the density of the animals, the equation:

$$
\mathrm{D}=\frac{\hat{\mathrm{N}}}{\mathrm{A}}
$$

$\hat{\mathrm{N}}=$ The estimated size of the population

$\mathrm{A}=$ The area occupied by the population

Also through, the 7 years annual population growth rates were estimated using (Mol, 1995) (Williams et al., 2001):

Where:

$$
\log N_{t}=\log N_{0}+r_{m} t(\log e)
$$

$\mathrm{N}_{\mathrm{t}}=$ Number of individual in the population in a given time

$\mathrm{N}_{0}=$ Number of individual at the beginning population

$\mathrm{r}_{\mathrm{m}}=$ Growth rate

$\mathrm{t}=$ Time

\section{RESULTS AND DISCUSSION}

The data provided drive counts between 2003 and 2010 were shown in Table 1 and these data were applied to descriptive statistics shown in Table 2 for red deer and roe deer. The standard error of mean was multiplied by the correction coefficient because of sampling without replacement and was used for estimating animal numbers:

Table 1: Drive counts' results for 62 sample areas between 2003 and 2010 \begin{tabular}{lllllllll}
\hline Type of deer & 2003 & 2004 & 2005 & 2006 & 2007 & 2008 & 2009 & 2010 \\
\hline
\end{tabular} Red deer

\begin{tabular}{lrrrrrrrr}
$\mathrm{B}_{\mathrm{d}}$ & 10 & 11 & 20 & 18 & 24 & 22 & 25 & 22 \\
$\mathrm{H}_{\mathrm{d}}$ & 16 & 18 & 23 & 35 & 26 & 27 & 34 & 32 \\
$\mathrm{C}_{\mathrm{d}}$ & 1 & 0 & 1 & 7 & 9 & 14 & 15 & 16 \\
$\mathrm{~T}_{\mathrm{d}}$ & 27 & 29 & 44 & 60 & 59 & 63 & 74 & 70 \\
Roe deer & & & & & & & & \\
$\mathrm{B}_{\mathrm{r}}$ & 33 & 28 & 34 & 33 & 36 & 34 & 48 & 48 \\
$\mathrm{H}_{\mathrm{r}}$ & 66 & 38 & 60 & 57 & 52 & 40 & 51 & 41 \\
$\mathrm{C}_{\mathrm{r}}$ & 10 & 26 & 20 & 18 & 14 & 21 & 28 & 16 \\
$\mathrm{~T}_{\mathrm{r}}$ & 109 & 92 & 113 & 108 & 102 & 95 & 127 & 105 \\
\hline
\end{tabular}

\begin{tabular}{|c|c|c|c|c|c|c|c|c|c|c|c|c|c|c|c|c|}
\hline \multirow[b]{2}{*}{ Years } & \multicolumn{8}{|c|}{ Red deer (Cervus elophus) } & \multicolumn{8}{|c|}{ Roe deer (Copreolus capreolus) } \\
\hline & 03 & 104 & 05 & 2006 & 2007 & 2008 & 009 & 010 & 003 & 004 & 2005 & 2006 & 007 & 008 & 2009 & 2010 \\
\hline $\mathrm{N}$ & 0 & 00 & 00 & 0 & 6 & 0 & 0 & 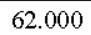 & & & & & & & 00 & 00 \\
\hline Mean & & & & & & & & & & & & & & & & \\
\hline SEM & 164 & 0.127 & 0.163 & 0.267 & 0.214 & 0.278 & 0.208 & 0.285 & 0.232 & 0.201 & 0.173 & 0.145 & 0.147 & 0.141 & 0.183 & 0.143 \\
\hline SD & 288 & 1.004 & 1.285 & 2.105 & 1.683 & 2.192 & 1.638 & 2.243 & 1.826 & 1.586 & 1.361 & 1.144 & 1.161 & 1.112 & 1.442 & 1.125 \\
\hline Variance & 1.660 & 1.007 & 1.652 & 4.425 & 2.834 & 4.803 & 2.683 & 5.032 & 3.334 & 2.516 & 1.853 & 1.309 & 1.347 & 1.237 & 2.080 & 1.265 \\
\hline Minimum & 0.000 & 0.000 & 0.000 & 0.000 & 0.000 & 0.000 & 0.000 & 0.000 & & 0.000 & 00 & 000 & 0.000 & 0.000 & 0.000 & 0.000 \\
\hline Maximum & 00 & 4.000 & 6.000 & 11.000 & 00 & 000 & 00 & 10.000 & 000 & 6.000 & 5.000 & 5.000 & 90 & 4.000 & 6.000 & 5.000 \\
\hline Sum & .000 & 29.000 & 44.000 & 60.000 & 59.000 & 63.000 & 74.000 & 70.000 & 109.000 & 92.000 & 113.000 & 108.000 & 102.000 & 95.000 & 127.000 & 05.000 \\
\hline
\end{tabular}

S: Buck, H: Hind; C: Calves; T: Total; d: Red deer; r: Roe deer

Table 2: Descriptive statistics results for red deer and roe deer between 2003 and 2010

$\mathrm{SEM}=$ Standard Error of Mean; $\mathrm{SD}=$ Standard Deviation 
Table 3: Estimated red deer and roe deer numbers and densities

\begin{tabular}{|c|c|c|c|c|c|}
\hline Type of deer & $\begin{array}{c}\text { Total } \\
\text { (individual) }\end{array}$ & Male & Female & Calves & $\begin{array}{c}\text { Animal density } \\
\text { (per } 100 \text { ha) }\end{array}$ \\
\hline \multicolumn{6}{|l|}{ Red deer } \\
\hline $\mathbf{N}_{\mathrm{d} 2003}$ & $224 \pm 154$ & 83 & 133 & 8 & 0.44 \\
\hline$\hat{N}_{\mathrm{d}} \mathrm{d} 2004$ & $239 \pm 119$ & 91 & 148 & 0 & 0.47 \\
\hline$N_{\sim} N_{d x o s}$ & $361 \pm 153$ & 164 & 189 & 8 & 0.71 \\
\hline $\mathrm{N}_{\mathrm{d} 2006}$ & $494 \pm 249$ & 148 & 288 & 58 & 0.97 \\
\hline $\mathbf{N}_{\mathrm{d} 2007}$ & $484 \pm 200$ & 197 & 213 & 74 & 0.95 \\
\hline$\hat{N}_{\mathrm{d} 2008}$ & $519 \pm 260$ & 181 & 223 & 115 & 1.02 \\
\hline$\hat{N}_{\mathrm{d} 2009}$ & $606 \pm 195$ & 205 & 278 & 123 & 1.19 \\
\hline $\mathrm{N}_{\mathrm{d} 2010}$ & $575 \pm 267$ & 181 & 263 & 131 & 1.13 \\
\hline \multicolumn{6}{|l|}{ Roe deer } \\
\hline$\hat{\mathrm{N}}_{\mathrm{r} 2003}$ & $896 \pm 220$ & 271 & 543 & 82 & 1.76 \\
\hline $\mathbf{N}_{x 2004}$ & $753 \pm 189$ & 230 & 311 & 213 & 1.48 \\
\hline$\hat{\mathbf{N}}_{\mathrm{r} 2005}$ & $937 \pm 160$ & 280 & 493 & 164 & 1.84 \\
\hline$\hat{\mathbf{N}}_{r 2006}$ & $886 \pm 136$ & 271 & 468 & 148 & 1.74 \\
\hline $\mathrm{N}_{\mathrm{r} 2007}$ & $840 \pm 138$ & 296 & 428 & 116 & 1.65 \\
\hline $\mathbf{N}_{r 2008}$ & $779 \pm 132$ & 279 & 328 & 172 & 1.53 \\
\hline$\hat{N}_{r 2009}$ & $1043 \pm 171$ & 394 & 419 & 230 & 2.05 \\
\hline $\mathrm{N}_{r 2010}$ & $860 \pm 133$ & 393 & 336 & 131 & 1.69 \\
\hline
\end{tabular}

Table 4: Annual growth rate of red deer and roe deer

\begin{tabular}{lrr}
\hline Years & $\mathrm{r}_{\mathrm{m}}$ red deer & $\mathrm{r}_{\mathrm{m}}$ roe deer \\
\hline 2004 & 0.06486100 & -0.17399300 \\
2005 & 0.41269400 & 0.21876600 \\
2006 & 0.31387000 & -0.05600400 \\
2007 & -0.02046400 & -0.05335100 \\
2008 & 0.06986600 & -0.07544200 \\
2009 & 0.15508100 & 0.29204300 \\
2010 & -0.05254600 & -0.19305500 \\
Average & 0.13476624 & -0.00586226 \\
\hline
\end{tabular}

$$
\sqrt{\frac{\mathrm{N}-\mathrm{n}}{\mathrm{N}-1}}=0.938
$$

In 2009, determined the number and density of red deer and roe deer was higher than the other years was 74 red deer and was 127 roe deer. In 2004, red deer calve was not observed and one calve was determined in 2003 and 2005. The means of red and roe deer populations were estimated for red deer min. 0.44 and max. 1.19; for roe deer min. 1.48 and $\max .2 .05$ (Table 2).

In this study, it was estimated red and roe deer numbers for whole study area. The estimated numbers of red deer and roe deer were shown in Table 3 . Their annual growth rates were shown in Table 4. According to Table 4, average of annual growth rates were estimated for red deer (0.135) and roe deer (-0.0059). In addition, the growth rate of red deer was found as decreasing and growth rate of roe deer was found as independent for 8 years.

The results of the counting done over eight years at the Wildlife Reserve were applied to ANOVA and Test of Homogenity of Variance for red deer and roe deer. Since, their significance levels were found $>0.05$ and the results were applied to Non-Parametric Methods Kruskal-Wallis $\mathrm{H}$ test of K-Independent Sample tests. According to Kruskal Wallis test, it was found for red deer (Asymp. Sig.
0.029), for roe deer (Asymp. Sig. 0.344). To evaluate about wildlife population increasing or decreasing or its trend, it should be monitored for many years. In terms of this, the study provides important results about red deer and roe deer numbers and their density and represents as an important model for the other Wildlife Reserves in Turkey. The estimated number of red deer was found as $575 \pm 267$ and density was $1.13 \mathrm{deer} / \mathrm{km}^{2}$ in 2010 . The average of red deer density for 8 years is $0.54 / \mathrm{km}^{2}$. In Europe, red deer density per $\mathrm{km}^{2}$ has changed between 2 and 10 animals $/ \mathrm{km}^{2}$. The highest density was found in Liechtenstein (2.81 animals $/ \mathrm{km}^{2}$ ), Austria (1.79), UK (1.47) and Luxembourg (1.23) (Burbaite and Csanyi, 2009). Although, the Wildlife Reserve is a protected area, the density of red deer in Wildlife Reserve is lower than European countries.

Red deer carrying capacity of a forest changes according to many researchers but the minimum of carrying capacity was given between 2 and 3 red deer $/ \mathrm{km}^{2}$ by Bruinderink and Lammertsma (1997), Ratcliffe (1997), Palmer et al. (1997) and Baleisis and Bluzma (1999). Thus, the study area is thought not to be reached to the carrying capacity of red deer because red deer density was found $1.13 \mathrm{red}$ deer $/ \mathrm{km}^{2}$ in 2010 .

Between 2003 and 2005, calves of red deer were not observed during the counting. Red deer calves might have been hidden by lying in the vegetations during the counting. Thus, calves weren't detected by both drivers and observers. Also red deer numbers were found lower than the other years.

The estimated number of roe deer was found as $860 \pm 133$ and density was $1.69 / \mathrm{km}^{2}$ in 2010 . The average of roe deer density is $1.72 / \mathrm{km}^{2}$ for 8 years. According to Burbaite and Csanyi (2009) roe deer density in Denmark (9.28 animals $\mathrm{km}^{-2}$ ), Luxembourg (9.27), Austria (8.94), Germany (8.40), in Europe, average of density is 1.55 animals per $\mathrm{km}^{2}$. Although, the average of roe deer density in the study area was found higher than Europe's average. It should be noted that because of being a protected area, it would be expected higher numbers of roe deer density in the study area such as in Austria, Denmark and Germany.

The result of the Kruskal-Wallis test showed that significance levels were found for roe deer (Sig. 0.344) and red deer (Sig. 0.029). Consequently, the change of red deer population was found as significant but the change of roe deer population wasn't found as significant. The averages of annual growth rate of these species were examined for 7 years. This rate was estimated for red deer as 0.135 and for roe deer as 0.0059 . This result means that whilst red deer population has been increasing and the roe deer population has been decreasing for long term period (Table 4). Roe deer numbers has declined in Europe only a few countries, two possible reasons could be 
responsible for this: the insufficient data and high level poaching (Burbaite and Csanyi, 2009). Since, roe deer gives birth as twins a year (Danilkin and Hewison, 1996) and normally population density can be expected to increase for long term period. Although, many predator species such as wolf and jackal live in the study area but the responsible of decreasing roe deer population can be thought as poaching is a reality of the study area. Poaching has been done mostly by the villagers and forestry workers from villages around the Wildlife Reserve. Since, red deer prefer to live in the center of the Wildlife Reserve where is far from the villages. Also there is a national park called Yedigoller National Park in the center of the Wildlife Reserve, provides better protection than outer line of Wildlife Reserve. Poachers avoid hunting around the national park because of the visitors and recreational usage of national park.

\section{CONCLUSION}

In this study it is aimed to determine and monitor deer density in Wildlife Reserve for long term period. According to the study results although, red deer density has increased and roe deer density has showed fluctuation, both red deer and roe deer' density of the study area can be thought lower than carrying capacity. To improve both red deer and roe deer density, adequate conservation management should be implemented in the area.

\section{ACKNOWLEDGEMENTS}

Thanks to Bolu Provincial Directorate of Environment and Forestry Director's Sezgin Akay, Branch Directorate of Nature Protection and National Parks Director's Ozkan Yavuz and Forest Ranger Mustafa Sezkin, Dursun Dikmen, Ruhi Aldal, Ismail Ozcan, Kemalettin Karakanli, Mustafa Kirbanci and all other staff. Also, thanks to Assist. Prof. Dr. Ersel Yilmaz for helping the statistics of the study.

\section{REFERENCES}

Adrados, C., C. Baltzinger, G. Janeau and D. Pepin, 2008. Red deer Cervus elaphus resting place characteristics obtained from differential GPS data in a forest habitat. Eur. J. Wildl. Res., 54: 487-494.

Al-Hashem, M., 2009. Effects of oil pollution on the population size of the desert lizard Acanthodactylus scutellatus and their ant prey at Kuwait's Al-burgan oil field. J. Biol. Sci., 9: 682-686.

Baleisis, R. and P. Bluzma, 1999. State of the red deer population, its dynamics and impact on the habitats on the zagare botanical-zoological reserve. Acta Zool. Lithuanica, 9: 49-54.
Bruinderink, G. and D.R. Lammertsma, 1997. Management of red deer in netherlands, population ecology. Proceedings of the Population Ecology Management and Welfare of Deer, April 1997, The Manchester Metropolitan University, Manchester, pp: 88-94.

Burbaite, L. and S. Csanyi, 2009. Roe deer population and harvest changes in Europe. Est. J. Ecol., 58: 169-180.

Caughley, G. and A.R.E. Sinclair, 1994. Wildlife Ecology and Management. 5th Edn., Blackwell Science, Massachussets, Pages: 334.

Costa, S.S., D.B. Oliveira, A.M. Manco, G.O. De Melo and J.L.P. Cordeiro et al., 2006. Plants composing the diet of marsh and pampas deer in the Brazilian pantanal wetland and their ethnomedicinal properties. J. Boil. Sci., 6: 840-846.

Danilkin, A. and A.J.M. Hewison, 1996. Behavioural Ecology of Siberian and European Roe Deer. Chapman and Hall, London, UK., Pages: 277.

Gundogdu, E., 2011. Population size, structure and behaviours of wild goat in cehennemdere wildlife improvement area. Asian J. Anim. Vet. Adv., 6: 555-563.

Kumbasli, M., E. Makineci And M. Cakir, 2010. Long term effects of red deer (Cervus elaphus) grazing on soil in a breeding area. J. Environ. Biol., 31: 185-188.

Marques, F.F.C., S.T. Buckland, D. Goffin, C.E. Dixon, D.L. Borchers, B.A. Mayle and A.J. Peace, 2001. Estimating deer abundance from line transects survey of dung: Sika deer in Southern Scotland. J. Applied Ecol., 38: 349-363.

Milner, J.M., C. Bonenfant, A. Mysterud, J.M. Gaillard, S. Csanyi and N.C. Stenteth, 2006. Temporal and spatial development of red deer harvesting in Europe: Biological and cultural factors. J. Applied Ecol., 43: 721-734.

Palmer, S.C.F., I.S. Paterson, M. Marquiss and B.W. Staines, 1997. The impact of deer browsing on regeneration of scots pine: A preliminary study. Proceedings of the Population Ecology Management and Welfare of Deer, April 1997, Manchester Metropolitan University, Manchester, pp: 48-53.

Patthey, P., 2003. Habitat and corridor selection of an expanding red deer (Cervus elaphus) population. Ph.D. Thesis, Institute of Ecology, University of Lausanne.

Prokesova, J., M. Barancekova and M. Homolka, 2006. Density of red and roe deer and their distribution in relation to habitat characteristics in a floodplain forest. Folia Zool., 55: 1-4.

Pudyatmoko, S., Kaharuddin and S. Nurvianto, 2009. Role of urban environment on conservation of birds diversity in Java, Indonesia. J. Biol. Sci., 9: 345-350. 
Qureshi, B.D., M.S. Awan, A.A. Khan, N. Iftikhar Dar and M. Ejaz-ul-Islam Dar, 2004. Distribution of himalayan musk deer (Moschus chrysogaster) in Neelum valley, district Muzaffarabad, Azad Jammu and Kashmir. J. Biological Sci., 4: 258-261.

Ratcliffe, P.R., 1997. Woodland deer management: Integrating the control of their impact with multiple objective forest management in Scotland. Proceedings of the Population Ecology Management and Welfare of Deer, April 1997, Manchester Metropolitan University, Manchester, pp: 67-72.
Siddique Awan, M., A. Ahmed Khan, K. Basharat Ahmed, M. Ahmed Qureshi, M. Ahmed Malik and N. Iftikhar Dar, 2004. Population dynamics of cheer pheasant (Catreus wallichii) in Jhelum Valley, Muzaffarabad, Azad Kashmir, Pakistan. Pak. J. Biol. Sci., 7: 789-796.

Williams, B.K., J.D. Nichols and M.J. Conroy, 2001. Analysis and Management of Animal Populations, Modeling, Estimation and Decision Making, Academic Press, London, Pages: 817. 